GROSE, Timothy. 2019. Negotiating Inseparability in China:

The Xinjiang Class and the Dynamics of Uyghur Identity.

Hong Kong: Hong Kong University Press.

Ildikó Bellér-Hann

(C) OpenEdition

Journals

Electronic version

URL: https://journals.openedition.org/chinaperspectives/10482

DOI: 10.4000/chinaperspectives.10482

ISSN: 1996-4617

Publisher

Centre d'étude français sur la Chine contemporaine

Printed version

Date of publication: 1 September 2020

Number of pages: 65-66

ISSN: 2070-3449

Electronic reference

\|ldikó Bellér-Hann, “GROSE, Timothy. 2019. Negotiating

Inseparability in China: The Xinjiang Class and the

Dynamics of Uyghur Identity. Hong Kong: Hong Kong

University Press.", China Perspectives [Online], 2020-3 | 2020, Online since 01 September

2020, connection on 10 December 2021. URL: http://journals.openedition.org/chinaperspectives/

10482 ; DOI: https://doi.org/10.4000/chinaperspectives.10482

This text was automatically generated on 10 December 2021.

(c) All rights reserved 
GROSE, Timothy. 2019. Negotiating Inseparability in China:

The Xinjiang Class and the Dynamics of Uyghur Identity.

Hong Kong: Hong Kong University Press.

\section{Ildikó Bellér-Hann}

1 The institution of the Xinjiang Class (neidi Xinjiang gaozhongban 內地新疆高中班) was introduced in China in 2000. Based on the Tibetan model (neidi Xizang gaozhongban 內地西藏高中班), the fouryear boarding school was designed to provide high-quality Chinese language education for disadvantaged Uyghur and other minority students mostly from a rural background. Through generously funding such students in China's predominantly Han-populated cities far away from their homeland, the Xinjiang Uyghur Autonomous Region (XUAR), the program was supposed to integrate minority youth into mainstream Chinese society, imbuing them with Chinese values and thereby contributing to the stability of the "restive" north-western

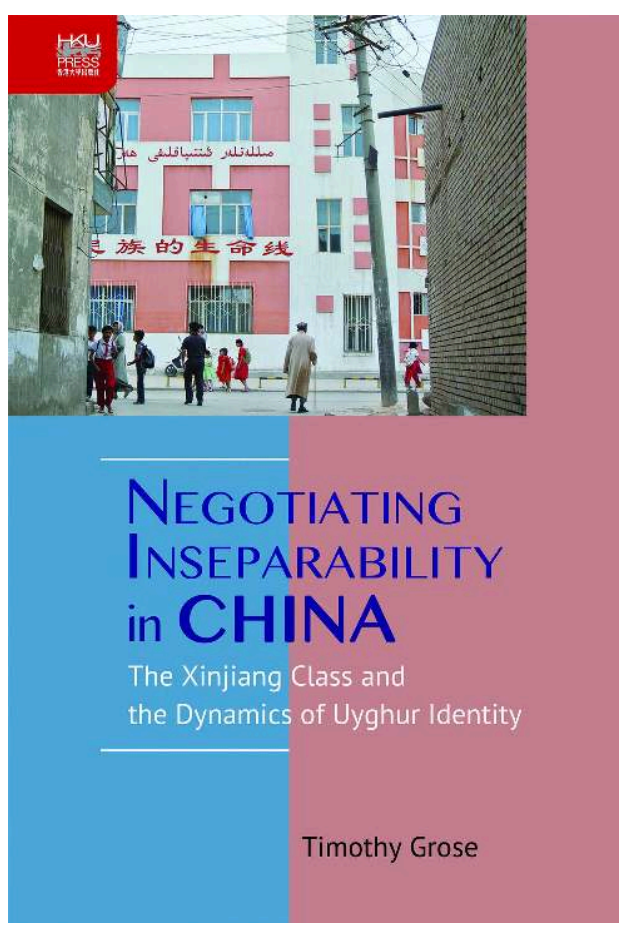
borderland. The main objective of the study is to assess the overall outcomes of this educational policy.

2 Based on 30 months of fieldwork in Beijing and in various oases of the XUAR between 2007 and 2017, Timothy Grose's book focuses on the Uyghurs, who make up the 
majority of the Xinjiang Class. He never received permission to participate in everyday school life and instruction, but using a snowball method he managed to interview 64 Uyghur graduates (male and female) about their experiences. He also draws on oral histories and official documents issued by the Ministry of Education, the Xinjiang Department of Education, and individual schools hosting Xinjiang Classes. Research was conducted both in Chinese and Uyghur. Grose's central analytical concepts are the state and Uyghur ethnic identity as defined by the state. It soon becomes clear that official recognition of ethnic diversity (rather than simply denying it) may engender discord: minority ethnicity has both beneficial and detrimental aspects. Preferential policies in the early years of market reforms included benefits in the fields of family planning, employment, and culture. From the 1990s, however, affirmative action gave way to intensifying discrimination that circumscribed use of the Uyghur language and culture in general, including religious expression. These repressive policies culminated in the mass incarcerations that began in 2016, which can be interpreted as a determined effort to secure the full assimilation of the Uyghurs.

Grose's exploration of Uyghur self-positioning vis-à-vis the Chinese state and diverse identity discourses builds on earlier scholarship. Modern Uyghur identity emerged in the borderlands of the Chinese and the Russian Empires. State policies shaped but did not invent collective identities. This continued after 1949, when minzu 民族 designation cemented Uyghur collective identity, albeit threatened by heavy-handed restrictions and the promotion of Han migration to the XUAR. While this narrative is well known, Grose breaks new ground when illuminating the multiple strategies through which Xinjiang Class graduates creatively relate to state-ascribed identities.

Chapter One introduces the institution and the motivations of the Chinese Communist Party. The boarding school offers able pupils an escape route from poverty and the prospect of studying at a top university in Eastern China. Behind the rhetoric of promoting inter-ethnic communication, the political objective is to create a fully Sinicised minority elite. About $80 \%$ of Xinjiang Class pupils are Uyghurs from southern Xinjiang. The presence of non-Uyghurs justifies reliance on Chinese in the classroom, where the curriculum is monolingual. Contact with Han is limited to the teacher-pupil relationship in the classroom: Han students live and study on the same campus, but in separate buildings. When inter-ethnic encounters with Han do occur, they tend to be played out in terms of competition and discursive patronising by the Han.

Minority boarders are subjected to a strict regime of study and are required to wear standardised uniforms. Quotidian expressions of religiosity as well as veiling are forbidden. The absence of the Uyghur language in the classroom contradicts the principles of minzu policies, which encourage use of the mother tongue. While Uyghur students comply with the schools' religious policies, they subvert its language policy by using Uyghur systematically outside the classroom.

Chapter Two investigates how Uyghur students assert their ethnic identity away from their homeland. Ethnographic vignettes and interview excerpts testify to creative responses to the state's efforts to replace indigenous with patriotic loyalties. Taking advantage of the relative freedom of conditions in Inner China, Uyghur pupils embrace transnational Muslim cosmopolitanism, from which, however, Chinese Muslims (Hui 回), who form a separate ethnic group and display greater cultural proximity to the Han majority than the Uyghur, remain excluded. Different modes of communication require diverse modes of language. While face-to-face communication relies 
overwhelmingly on Uyghur as an expression of corporate ethnic identity, electronic communication allows some space for the inclusion of Chinese. Everyday resistance is particularly salient in dating practices, where communal and family pressure inhibit inter-ethnic romantic relationships and intermarriage.

7 Chapter Three explores Xinjiang Class graduates' career choices after they have completed another four years of college away from Xinjiang. Defying government propaganda that encourages them to pay back their debt to the government by returning to work in Xinjiang, many Uyghurs seek employment either abroad or in other parts of China. However, as we learn in Chapter Four, few are successful and most return to Xinjiang eventually, often reluctantly, yielding to family pressure, administrative constraints concerning their mobility and place of residence, and economic insecurity. Religion poses a particular dilemma when deciding whether to return to Xinjiang or not. In Han-majority regions it is difficult to follow a halal diet, while within Xinjiang the increased surveillance and extreme restrictions placed on religious practice were seen as major drawbacks.

The overall conclusion is that the Xinjiang Class ultimately fails to achieve its desired outcomes. During their eight to nine years away from the homeland, Uyghur graduates resist integration: if anything, living in Han-majority surroundings strengthens their Uyghur ethnic identity.

This comprehensive yet concise study of the experiences of Uyghur Xinjiang Class graduates studying in Eastern China is timely. Grose captures the complex relationship between Uyghur agency and state efforts to impose primordial ethnic identity. The study is a major achievement, especially in view of the fact that conditions for data collection on such a sensitive topic by a foreign researcher were already becoming very difficult. Rather than present the Xinjiang Class in terms of Chinese exceptionalism, Grose makes appropriate comparisons with other nation-building projects, including British India, colonial France, and the United States government's dealings with Native American children.

By the time field research for this study was concluded, the Chinese state's relationship with the Uyghurs had deteriorated dramatically. It remains to be seen whether assimilation by coercion will prove any more successful than the failed policy of attempting to create a comprador elite by means of boarding schools.

\section{AUTHOR}

\section{ILDIKÓ BELLÉR-HANN}

Ildikó Bellér-Hann is Associate Professor at the Department of Cross-cultural and Regional Studies, University of Copenhagen. Dept. of Cross-cultural and Regional Studies, Karen Blixen plads 8, Copenhagen 2300 S., Denmark. ildiko@hum.ku.dk 